\title{
Haematological, Blood and Rumen Chemistry Changes in Lambs Following Supplementation with Se-yeast
}

\author{
Z. FAIXOVÁ, Š. FAIX ${ }^{2}$, L. LENG ${ }^{2}$, P.VÁCZI ${ }^{1}$, Z. MAKOVÁ, R. SZABÓOVÁ \\ Department of Pathology, Pathophysiology and Genetics \\ ${ }^{1}$ Department of Pharmacy, Pharmacology and Toxicology, University of Veterinary Medicine, \\ Košice, Slovak Republic \\ ${ }^{2}$ Institute of Animal Physiology, Slovak Academy of Sciences, Košice, Slovak Republic
}

Received March 16, 2006

Accepted October 20, 2006

\begin{abstract}
Faixová, Z., Š. Faix, L. Leng, P. Váczi, Z. Maková, R. Szabóová: Haematological, Blood and Rumen Chemistry Changes in Lambs Following Supplementation with Se-yeast. Acta Vet Brno 2007, 76: 3-8

The effects of feed supplementation with organic form of selenium (Se) on ruminal enzyme activities (ALT, AST, GGT, ALP and GDH), blood enzyme activity (GPx), serum enzyme activities (LDH, CK) and haematological indicators were examined in lambs. Ten animals were divided into two groups and fed experimental diets for 3 months. The first group received a basic diet (BD) providing a daily intake $50.6 \mu \mathrm{g}$ of Se only. The diet for the second group consisted of BD supplemented with selenium $0.3 \mathrm{mg} \cdot \mathrm{kg}^{-1} \mathrm{DM}$ in the form of Se-enriched yeast and giving a total daily intake $278 \mu \mathrm{g}$ of Se per animal. Lambs of the second group which were fed additional Se had increased concentrations of Se in plasma $(P<0.001)$, greater activity of blood glutathione peroxidase $(\mathrm{GPx})(P<0.001)$ and lower activity of creatine kinase $(\mathrm{CK})(P<0.05)$ in serum. The activity of alkaline phosphatase (ALP) $(P<0.001)$ and glutamate dehydrogenase (GDH) $(P<0.001)$ in ruminal fluid were found to be significantly higher in Se-yeast group of lamb compared with the group given BD with no differences for Se concentration in ruminal fluid and ALT, AST and GGT activities. Total erythrocyte count and osmotic resistance of red blood cells were significantly higher $(P<0.01)$ in selenium-supplemented animals. White blood cell count was increased in lambs given $\mathrm{BD}(P<0.05)$. It was concluded that Se supplementation can influence ruminal enzyme activities and cell membrane resistance of lambs.
\end{abstract}

Selenium; haematology; ruminal enzyme activity; sheep

Nutritional deficiences of selenium in sheep cause white muscle disease in lamb (Muth et al. 1958), loss of glutathione peroxidase activity (GSHPx; Rotruck et al. 1973), reduced selenoproteins (Croteau et al. 1996; Yeh et al. 1997), and suppression of immunity (Yamini and Mullaney 1985).

According to NRC Standards (1989) feeds used for ruminants should contain from 0.1 to $0.3 \mathrm{mg}$ selenium $/ \mathrm{kg}$ DM.

The availability of selenium from mineral compounds (sodium selenite, sodium selenate) in the gastro-intestinal tract of ruminants is poor. Low absorption of selenium in ruminants is believed to result from reduction of dietary selenium to insoluble forms such as elemental selenium or selenides in the rumen environment (Peter son and Spedding 1963; Várady et al. 2005).

It was found that organic selenium in selenized yeast resulted in much larger increases in blood and milk selenium concentrations than selenite (Knowles et al. 1999; Orthman and Pehrs on 1999). Lambs fed selenomethionine also had higher selenium concentrations in skeletal muscle and in a number of other tissues than lambs fed selenite (Ehling et al. 1967). Selenomethionine is the predominant form of selenium that occurs naturally in feedstuffs and selenized yeast. Incorporation of selenomethionine into non-specific body 
proteins in place of methionine (B ehne et al. 1991) probably explains the higher selenium concentrations in tissues and milk of ruminants that were fed organic compared with selenite selenium.

Absorption of selenium in ruminants depends on several factors. Limited research suggests that either high or low dietary calcium may reduce selenium absorption (Harris on and Conrad 1984). Gutzwiller (1993) reported that ewes fed a white-clover variety that was high in cyanogenetic glycosides had much lower selenium status. Later Koenig et al. (1997) found that selenium absorption and retention were greater in sheep fed a concentratebased (barley) diet than in those fed a forage-based (alfalfa hay) diet. A number of studies indicate that increasing dietary sulfur reduces the bioavailability of selenium (Iv ancic and Wiess 2001). Recently Pavlata et al. (2005) reported that increased iodine supplementation may have a negative effect on selenium metabolism and/or status in kids.

The objective of this study was to determine the effect of feed supplementation with selenized yeast on selected haematological indicators and blood, serum and ruminal enzyme activities in lambs.

\section{Materials and Methods}

The experiment was carried out on 10 male lambs of Valaška breed at the age of four months divided into 2 groups of 5 animals and kept on diets that differed in the content of Se supplemented. Animals were housed in individual pens with free access to water and fed both the diets used for 3 months before sampling. The lambs weighed from 18 to $20 \mathrm{~kg}$ at the end of experiment.

The composition of the daily ration of basic diet (BD) per lamb and the daily delivery of Se by BD is presented in Table 1.

Table 1. The composition of the daily ration of basic diet per lamb and Se intake

\begin{tabular}{|l|c|c|c|c|}
\hline \multicolumn{1}{|c|}{ Component } & $\begin{array}{c}\text { Amount } \\
(\mathrm{g})\end{array}$ & $\begin{array}{c}\text { Dry mater } \\
(\mathrm{g})\end{array}$ & $\begin{array}{c}\text { Content of Se } \\
(\mu \mathrm{g} / \mathrm{kg} \text { of DM })\end{array}$ & $\begin{array}{c}\text { Se intake } \\
(\mu \mathrm{g} / \mathrm{day})\end{array}$ \\
\hline Hay & 500 & 440.0 & 61.9 & 27.2 \\
\hline Rapeseed oilmeal & 40 & 36.3 & 166.5 & 6.1 \\
\hline Barley & 300 & 259.0 & 66.8 & 17.3 \\
\hline Total & 840 & 735.3 & 295.2 & 50.6 \\
\hline
\end{tabular}

The first group was given BD with the daily Se content of $50.6 \mu \mathrm{g}$ coming from the natural occurrence of Se in the dietary component only. The second group received BD supplemented with $0.3 \mathrm{mg}$ of Se in the form of Seyeast extract (Sel-Plex, Alltech Inc., USA) giving the daily Se intake $278.6 \mu \mathrm{g}$. The diet for the $1^{\text {st }}$ group was fortified with adequate amounts of the yeast extract without Se (NUPRO, Alltech Inc., USA) to obtain the same final levels of the yeast extract as in the $2^{\text {nd }}$ group (daily intake $1.04 \mathrm{~g}$ of NUPRO in feed).

EU requirements related to laboratory animal welfare were met.

Sample analysis

One heparinized and one non-heparinized tube of blood were collected from each lamb at 06:00 $\mathrm{h}$ before the morning feeding. Plasma was removed after blood centrifugation at $1,180 \times g$ for 15 min. Blood collected in nonheparinized tubes was centrifuged at $2,000 \times g$ for $20 \mathrm{~min}$ and the serum was decanted and frozen.

The concentrations of selenium in dietary components, samples of plasma and rumen fluid were measured by fluorometric method of Rodriguez et al. (1994).

The enzymes, lactate dehydrogenase LD (LD 50, BIO-La-TEST, CzR) and creatine kinase CK (CK 50, BIOLACHEMA-TEST, CR) were assayed in serum according to procedures outlined in respective commercial kits using a spectrophotometer set at 500 and $400 \mathrm{~nm}$ wavelenght. The enzyme, glutathione peroxidase, GPx (GPx, RANSEL, RANDOX, UK) was assayed in blood according to procedure outlined in commercial kit using a spectrophotometer set at $340 \mathrm{~nm}$ wavelenght.

The haemocytometer method was used for total erythrocyte and total leukocyte count determination. Erythrocyte osmotic fragility test was performed according to the method of Coles (1986).

Ruminal fluid collection

Ruminal fluid was obtained by means of a silicone tube attached to a vacuum source through each ruminal cannula 2 hours after the morning feeding. The ruminal fluid was strained through four layers of cheesecloth within 30 min of collection. 
The enzymes, alanine aminotransferase, ALT (ALT 360, BIO- LACHEMA-TEST, CzR), aspartate aminotransferase, AST (AST 360, BIO-LACHEMA-TEST, CzR), gamma-glutamytransferase, GGT (GGT 100, BIO-LACHEMA-TEST, CzR), alkaline phosphatase, ALP (ALP 120, BIO-LACHEMA-TEST, CR) and glutamate dehydrogenase, GDH (GL 442, RANDOX, UK) were assayed in rumen fluid according to procedures outlined in respective commertial kits using a spectrophotometer set at 510, 510, 430, 420 and $340 \mathrm{~nm}$ wavelenght, respectively.

The results are expressed as mean \pm S.E.M. Statistical significance was evaluated by unpaired Student's $t$-test.

\section{Results and Discussion}

The selenium concentration in plasma was significantly higher in lambs given Sesupplement (Table 2). This agrees with a study by Chen and Lin (2000) who reported that the Se concentration in serum was significantly increased after $\mathrm{SeO}_{2}$ treatment compared to control. Later Rock et al. (2001) found that Se supplementation to pregnant ewes either from sodium selenite or selenized yeast increased the concentration of Se in serum of both pregnant ewes and lambs of ewes given Se.

Table 2. Effect of supplemental Se on haematological indicators of lambs

\begin{tabular}{|l|c|c|c|}
\hline Parameter & Control & Selenized yeast & \\
\hline RBC (T/l) & $5.65 \pm 0.17$ & $7.77 \pm 0.45$ & $P<0.01$ \\
\hline WBC (G/l) & $7.32 \pm 0.92$ & $4.57 \pm 0.33$ & $P<0.05$ \\
\hline Fragility of RBCs & & & NS \\
a, minimal & $0.64 \pm 0.02$ & $0.61 \pm 0.01$ & $P<0.01$ \\
b, maximal & $0.50 \pm 0.0$ & $0.42 \pm 0.02$ & \\
\hline
\end{tabular}

Results are expressed as mean of five determinations \pm S.E.M. Statistical significance of the differences between groups was determined by unpaired Student's $t$-test.

Table 3. Effect of supplemental Se on plasma concentration of selenium and activities of lactate dehydrogenase and creatine phosphokinase in serum and glutathione peroxidase in blood of lambs

\begin{tabular}{|l|c|c|c|}
\hline Indicator & Control & Selenized yeast & \\
\hline $\mathrm{Se}(\mu \mathrm{mol} / \mathrm{l})$ & $0.39 \pm 0.02$ & $1.78 \pm 0.05$ & $P<0.001$ \\
\hline $\mathrm{LDH}(\mu \mathrm{kat} / \mathrm{l})$ & $7.40 \pm 0.51$ & $7.50 \pm 0.52$ & $\mathrm{NS}$ \\
\hline $\mathrm{CK}(\mu \mathrm{kat} / \mathrm{l})$ & $2.63 \pm 0.09$ & $1.73 \pm 0.29$ & $P<0.05$ \\
\hline $\mathrm{GPx}(\mathrm{U} / \mathrm{g} \mathrm{Hb})$ & $142.02 \pm 21.72$ & $830.85 \pm 69.23$ & $P<0.001$ \\
\hline
\end{tabular}

Results are expressed as mean of five determinations \pm S.E.M. Statistical significance of the differences between groups was determined by unpaired Student's $t$-test.

Activity of GPx was greater $(P<0.001)$ in lambs supplemented with Se (Table 3$)$. A high and linear correlation between the Se concentration and GPx activity of blood has been reported by several authors (Pavlata et al. 2001; Rock et al. 2001). Our results confirm the positive correlation between blood Se content and the activity of this selenoenzyme.

However, Se concentrations in rumen fluid of lambs were not affected by $\mathrm{Se}$ supplementation (Table 4).

The fate of seleno-methionine in rumen depends on whether Se released from selenomethionine by rumen degradation is further degraded into inorganic Se or re-incorporated into microbial protein as seleno-methionine. Once absorbed, seleno-methionine can be incorporated into protein non-specifically in place of methionine; an excess of selenomethionine incorporation into protein can influence protein function of seleno-methionine replaces methionine at the active site of an enzyme (Schrauzer 2000). The extent of seleno-methionine incorporation into protein is dependent upon the methionine status of the animal: when methionine is limiting, incorporation of seleno-methionine is increased. Although seleno-methionine incorporated in protein has no known function, protein-bound 
Table 4. Effect of supplemental Se on ruminal concentration of selenium and activities of alanine aminotransferase, aspartate aminotransferase, alkaline phosphatase, $\gamma$-glutamyl transferase and glutamate dehydrogenase in ruminal fluid of lambs

\begin{tabular}{|l|c|c|c|}
\hline Indicator & Control & Selenized yeast & \\
\hline ALT $(\mu \mathrm{kat} / \mathrm{l})$ & $1.24 \pm 0.05$ & $1.41 \pm 0.17$ & $\mathrm{NS}$ \\
\hline $\mathrm{AST}(\mu \mathrm{kat} / \mathrm{l})$ & $2.3 \pm 0.13$ & $2.48 \pm 0.17$ & $\mathrm{NS}$ \\
\hline $\mathrm{ALP}(\mu \mathrm{kat} / \mathrm{l})$ & $1.7 \pm 0.08$ & $11.88 \pm 0.81$ & $P<0.001$ \\
\hline $\mathrm{GGT}(\mu \mathrm{kat} / \mathrm{l})$ & $2.47 \pm 0.39$ & $3.34 \pm 0.44$ & $\mathrm{NS}$ \\
\hline $\mathrm{GDH}(\mu \mathrm{kat} / \mathrm{l})$ & $0.16 \pm 0.009$ & $1.77 \pm 0.12$ & $P<0.001$ \\
\hline $\mathrm{Se}(\mu \mathrm{mol} / 1)$ & $0.012 \pm 0.003$ & $0.021 \pm 0.004$ & $\mathrm{NS}$ \\
\hline
\end{tabular}

Results are expressed as mean of five determinations \pm S.E.M. Statistical significance of the differences between groups was determined by unpaired Student's $t$-test.

seleno-methionine may act as a source of Se in deficiency providing possible local stores for muscle.

Activities of alkaline phosphatase and glutamate dehydrogenase in ruminal fluid were significantly higher $(P<0.001)$ in Se-supplemented lambs compared to control lambs (Table 3$)$.

Numerous studies have addressed the effects of selenium on the digestibility of nutrients. Naziroglu et al. (1997) reported that combined supplementation of Se and vitamin E increased acetic, propionic, butyric and total volatile fatty acid concentration, the total counts of protozoa of the ruminal fluid of lambs in vivo. However, there was no statistically significant difference between the control and selenium and vitamin E-supplemented group in the ammonia nitrogen level. Kim et al. (1997) investigated the effect of several forms of selenium on ruminal microbial fermentation in vitro using rumen microflora from fistulated dairy cow. They reported that selenium supplementation could influence rumen microbial fermentation and that $\mathrm{Se}$ compounds tested, the amounts of short-chain fatty acids were greater with Se-Met treatment, which yielded a higher proportion of acetate compared to elemental Se and sodium selenite.

However, there is only scarce information about the effect exerted by selenium on rumen enzyme activities. Significantly higher activity of alkaline phosphatase and glutamate dehydrogenase in ruminal fluid in Se-supplemented group can be explained by its supportive effect on rumen microbial population, increasing their resistance and activity. In addition, selenium is known to act as a scavenger of free radicals within cell membranes, having a protective effect against oxidative damage.

Total erythrocyte count and osmotic resistance of $\mathrm{RBCs}$ were increased by $\mathrm{Se}$ supplementation $(P<0.01)$. On the other hand, white blood cell count was increased in lambs given basic diet $(P<0.05)$. A positive effect of selenium on haematological indicators was observed by several authors (Horton et al. 1978; Sehgal et al. 1980; Doni et al. 1984; Li et al. 1990; Chen and Lin 2000; Tras et al. 2000), but not confirmed by others ( $\mathrm{Hu}$ et al. 1984; Bednarek et al. 1996). Fragility of erythrocyte membranes was significantly decreased in $\mathrm{SeO}_{2}$-treated rats compared to control (Chen and $\mathrm{Lin} 2000$ ). However, Tras et al. (2000) found that none of the haematological indicators (red blood cell count, haemoglobin, packed cell volume) were affected by a diet supplemented with vitamin $\mathrm{E}+$ selenium in male broiler chicken but ascorbic acid + aspirin + vitamin $\mathrm{E}$ and selenium supplementation significantly decreased the white blood cell counts.

A divergence of opinion as regards the effects of Se on haematological indicators was often presented in literature. One of the reasons is the fact that the effect of selenium was mostly examined simultaneously with that of vitamin $\mathrm{E}$ and/or ascorbic acid, which made the interpretation difficult.

The results presented here show a positive effect of selenium on the membrane stability of red blood cells and the red blood cell count. 
Our study shows that there was an increase in CK activity in the animals in the control group $(P<0.05)$. However, creatine phosphokinase activity in both control and Sesupplemented lambs was within the physiological norm. There were no clinical cases of nutritional muscular dystrophy. Sekin et al. (1996) reported that CK activity is correlated with intensive degenerative changes in the muscle, whereas Bradley et al. (1987) reported that the detection of $\mathrm{CK}$ activity is particularly useful in the diagnosis of subclinical states of dystrophy. Later Sobiech and Kuleta (2002) reported significantly higher CK activity in Se-deficient lambs.

Selenium-yeast supplementation to lambs increased the concentration of Se in plasma and blood glutathione peroxidase activity. In addition, Se supplementation increased the stability of red blood cells and red blood cell count and glutamate dehydrogenase and alkaline phosphatase activity in ruminal fluid of lambs.

\section{Zmeny v hematológii a v bachore po podaní selenizovaných kvasníc u jahniat}

Vplyv krmiva obohateného organickým selénom na aktivitu enzýmov v bachore (ALT, AST, GGT, ALP a GDH), v krvi (GPx), v sére (LDH a CK) a na hematologické parametre bol sledovaný u jahniat. Desat jahniat bolo rozdelených do dvoch skupín a kŕmených diétou počas troch mesiacov. Prvá skupina zvierat bola kŕmená základnou diétou, ktorá obsahovala 50,6 $\mu$ g selénu na 1 deň. Druhá skupina zvierat bola kŕmená základnou diétou suplementovanou o selén v dávke $0,3 \mathrm{mg} / \mathrm{kg}$ sušiny vo selenizovaných kvasníc a predstavovala dennú dávku $278 \mu$ g na 1 zviera. U jahniat druhej skupiny, ktoré boli kŕmené kŕmnou dávkou so zvýšeným obsahom selénu bola nameraná vyššia koncentrácia selénu v plazme $(P<0,001)$, vyššia aktivita enzýmu glutationperoxidáza (GPx) $(P<0,001)$ v krvi a nižšia aktivita enzýmu kreatinkináza $(\mathrm{CK})(P<0,05)$ v sére. Bolo zistené, že enzymatická aktivita alkalickej fosfatázy (ALP) $(P<0,001)$ a glutamát dehydrogenázy $(\mathrm{GDH})(P<0,001)$ v bachorovej tekutine bola vyššia u jahniat kŕmených diétou obsahujúcou selenizované kvasnice v porovnaní so skupinou kŕmenou základnou kŕmnou dávkou. Enzymatická aktivita ALT, AST a GGT v bachorovej tekutine oviec sa nelíšila medzi jednotlivými skupinami. Celkový počet erytrocytov a osmotická rezistencia erytrocytov boli signifikantne vyššie $(P<0,01)$ u zvierat suplementovaných selénom. Celkový počet bielych krviniek bol vyšší u jahniat $(P<0,05)$ kŕmených základnou diétou. Možno zhrnút, že suplementácia diéty selénom môže ovplyvnit enzymatickú aktivitu v bachore a odolnost̉ bunkových membrán u jahniat.

\section{Acknowledgments}

This work was supported by grants VEGA No. 1/2443/05 and No. 2/6173/6.

\section{References}

BEDNAREK D, KONRACKI M, CAKALA S 1996: Effect of selenium and vitamin E on white cells, serum concentration of several mineral and trace elements as well as immunological parameters in calves. Tieraerztl Wochenschr 103: 457-459

BEHNE DA, KYRIAZOPOULOS A, SCIED S, GESSNER H 1991: Effect of chemical form and dosage on the incorporation of selenium into tissue proteins in rat. J Nutr 121: 806-814

BRADLEY R, ANDERSON PH, WILESMITH JW 1987: Changing patterns of nutritional myodegeneration (white muscle disease) in cattle and sheep in the period 1975 - 1985 in Great Britain. Bovine Pract 22: 38-45

CHEN CY, LIN TH 2000. Effects of selenium dioxide on blood and femoral bone marrow of rats. J Toxicol Environ Health A 59: 553-560

COLES EH 1986: Veterinary Clinical Pathology. $4^{\text {th }}$ ed, Philadelphia:WB Saunder Company, pp. 436-437

CROTEAU W, DAVEY JC, GALTON VA, ST GERMAIN DL 1996: Cloning of the mammalian type II iodothyronine deiodinase: a selenoprotein differentially expressed and regulated in human and rat brain and other tissues. J Clin Invest 98: 405-417

DONI MG, FALANGA A, DELAINI F, VICENZI E, TOMASIAK M, DONATI MB 1984: The effect of vitamin E or selenium on the oxidant-antioxidant balance in rats. Br J Exp Pathol 65:75-80 
EHLING CF, HOGUE DE, ALLAWAY WH, HAMM DJ 1967: Fate of selenium from selenite or selenomethionine, with or without vitamin E, in lambs. J Nutr 92: 121-126

GUTZWILLER A 1993: The effect of a diet containing cyanogenetic glycosides on the selenium status and the thyroid function of sheep. Anim Prod 57: 415-419

HARRISON JH, CONRAD HR 1984: Effect of dietary calcium on selenium absorption by the nonlacting dairy cow. J Dairy Sci 67: 1860-1864

HORTON GM, JENKINS WL, RETIENMAIER R 1978: Haematological and blood chemistry changes in ewes and lambs following supplementation with vitamin E and selenium. Br J Nutr 40: 193- 203

HU ML, CHUNG C, SPALLHOLZ JE 1984: Haematologic data of selenium-deficient and selenium supplemented rats. J Inorg Biochem 22: 165-173

IVANCIC J, WEISS WJ 2001: Effect of dietary sulphur and selenium concentrations on selenium balance of lactating Holstein cows. J Dairy Sci 84: 225-232

KIM J, VAN SOEST PJ, COMBS GF Jr 1997: Studies on the effects of selenium on rumen microbial fermentation in vitro. Biol Trace Elem Res 56: 203-213

KNOWLES SO, GRACE ND, WURMS K, LEE J 1999: Significance of amount and form of dietary selenium on blood, milk and casein selenium concentrations in grazing cow. J Dairy Sci 82: 429- 437

KOENING KM, RODE LM, COHEN RD, BUCKLEY WT 1997: Effects of diet and chemical form of selenium on selenium metabolism in sheep. J Anim Sci 75: 817-827

LI FS, DUAN YJ, YAN SJ, GUAN JY, ZOU LM, WEI FC, MONG LY, LI L, LI SY 1990: Presenile (early ageing) changes in tissues of Kaschin-Beck disease and its pathogenic significance. Mech Ageing Dev 54: 103-120

MUTH OH, OLDFIELD JE, RENNERT LF 1958: Effect of selenium and vitamin E on white muscle disease. Science 128: 1090-1091

NATIONAL RESEARCH COUNCIL 1989. Nutrient Requirements of Domestic Animals, Nutrient Requirements of Dairy Cattle. $6^{\text {th }}$ revised Edition. National Academy of Sciences, National Research Council, Washington, D.C.

NAZIROGLU M, AKSAKAL M, CAY M, CELIK S 1997: Effect of vitamin E and selenium on some rumen parameters in lambs. Acta Vet Hung 45: 447-456

ORTHMAN K, PEHRSON B 1999: Effect of selenate as a feed supplement to dairy cows in comparison to selenite and selenium yeast. J Anim Sci 77: 3365-3370

PAVLATA L, ILLEK J, PECHOVÁ A 2001: Blood and tissue selenium concentration in calves treated with inorganic or organic selenium compounds - a comparison. Acta Vet Brno 70: 19-26

PAVLATA L, SLOSARKOVÁ S, FLEISCHER P, PECHOVÁ A 2005: Effects of increased iodine supply on the selenium status of kids. Vet Med-Czech 50: 186-194

PETERSON PJ, SPEDDING DJ 1963: The excretion of sheep of 75 selenium incorporation in red clover: the chemical nature of the excreted selenium and its uptake by three plant species. N Z J Agric Res 6: 13-23

ROCK MJ, KINCAID RL, CARSTENS GE 2001: Effect of prenatal source and level of dietary selenium on passive immunity and thermoregulation of newborn lambs. Small Ruminant Res 40: 129- 138

RODRIGEZ EM, SANZ MT, ROMERO CD 1994: Critical study of fluorometric determination of selenium in urine. Talanta 12: 2025-2031

ROTRUCK JT, POPE AL, GANTHER HE, SWANSON AB, HAFEMAN DG, HOEKSTRA WG 1973: Selenium, biochemical role as a component of GSHPx. Science 170: $588-590$

SEHGAL PK, BRONSON RT, BRADY PS, MC INTYRE KW, ELLIOT MW 1980: Therapeutic efficacy of vitamin $\mathrm{E}$ and selenium in treating hemolytic anemia of owl monkeys (Aotus trivirgatus). Lab Anim Sci 30: 92-98

SEKIN S, VOYVODA H, BIDLIK A, YUR F 1996: Importance of serum creatine kinase (CK), aspartate aminotransferase (AST) and lactate dehydrogenase in the diagnosis and prognosis of subclinical and clinical white muscle disease in lambs. Turk Veterin Hayvanc Dergisi 20: 225-230

SCHRAUZER GN 2000: Selenomethionine: a review of its nutritional significance, metabolism and toxicity. J Nutr 130: 1653-1656

SOBIECH P, KULETA Z 2002: Usefulness of some biochemical indicators in detection of early stages of nutritional muscular dystrophy in lambs. Small Ruminant Res 45: 209-215

TRAS B, INAL F, BAS AL, ALTUNOK V, ELMAS M, YAZAR E 2000: Effect of continuous supplementations of ascorbic acid, aspirin, vitamin $\mathrm{E}$ and selenium on some haematological parameters and serum superoxidase dismutase levels in broiler chickens. Br Poul Sci 41: 664-666

VÁRADY J, SOPKOVÁ D, JANKUROVÁ J 2005: Prestup amoniaku cez bachorovú sliznicu jahniat a oviec $\mathrm{v}$ podmienkach in vitro. Agriculture (Polnohospodárstvo) 51: 180-184 (In Slovak)

YAMINI B, MULLANEY TP 1985: Vitamin E and selenium deficiency as a possible cause of abortion in food animals. In: Proc. "28th Annual Management American Association Veterinary laboratory Diagnosis", Madison, WII, pp. 131-144.

YEH J, GU Q, BEILSTEIN MA, FORSBERG NE, WHANGER PD 1997: Selenium influences tissue levels of selenoprotein W in sheep. J Nutr 127: 394-402 